\title{
Impacts of Storage Duration and Materials on the Quality of Rainwater in Ogbomoso, Southwest Nigeria
}

\author{
T.P. Abegunrin ${ }^{1}$, G.O. Awe ${ }^{2}$, A.Y. Sangodoyin ${ }^{3}$, O.E. Onofua ${ }^{1}$ and O.M. Oguntoye ${ }^{1}$ \\ ${ }^{1}$ Department of Agricultural Engineering, LadokeAkintola University of Technology, \\ Ogbomoso, Nigeria \\ ${ }^{2}$ Department of Soil Resources and Environmental Management, Ekiti State University, \\ Ado Ekiti, Nigeria \\ ${ }^{3}$ Department of Agricultural and Environmental Engineering, University of Ibadan, \\ Ibadan, Nigeria \\ *Corresponding author
}

\section{A B S T R A C T}

Keywords

Rainwater harvesting, Quality indicators, Storage duration, Storage material.

\section{Article Info}

Accepted:

30 June 2017 Available Online: 10 July 2017

\begin{abstract}
Alternative water sources for potable or non-potable purposes are now sought as a result of the global crisis of water shortage and rainwater harvesting is one of the several strategies for mitigating the growing water crisis. However, one of the primary issues regarding the use of rainwater is quality. The objective of this study therefore was to examine the combined effects of storage duration and materials on the physico-chemical and microbiological qualities of harvested rainwater in Ogbomoso, southwestern Nigeria. Samples of harvested rainwater were kept in three different storage materials, namely metal drum (M), plastic drum (P) and earthen pot (E) for one day (D1), five days (D5) and ten days (D10) before analysis for quality indicators of physical, chemical and biological characteristics. Storage material had significant effect on the quality indicators except temperature, chloride $(\mathrm{Cl})$ and nitrite $\left(\mathrm{NO}_{2}\right)$ with earthen pot most significantly influencing the quality of the harvested rainwater. Except for temperature, total solids (TS), nitrate $\left(\mathrm{NO}_{3}\right)$ and total coliform (TC), storage duration did not significantly affect the quality indicators. As the storage duration increases, the introduction of contaminants increased the electrical conductivity (EC), TS and TC. There was significant correlation between the harvested rainwater quality indicators and of all the quality indicators, only changes in water temperature and chloride can be best predicted over time. This study shows that harvested rainwater for potable purposes should not be stored more than five days without adequate treatment and the use of plastic drum is recommended for storing rainwater. Nevertheless, care must be taken when storing rainwater from the introduction of foreign contaminants while proper handling must be ensured.
\end{abstract}

\section{Introduction}

Freshwater is an essential requirement for human existence. At the domestic level, water of acceptable quality at reasonable quantity is required for normal physiological needs and for sanitary purposes. Over the last half- century, water demand has increased and signs of water shortage have become common place (Miller, 1989; IPPC, 1990; Matondo et al., 2005; Kaldellis and Kondili, 2007). The shortage of water may be attributed to some 
factors among which are complexity in lifestyles, competition for freshwater among the various users (agriculture, industry, domestic and recreation), population increase, total or partial failure of conventional methods of water supply (Pinfold et al., 1993; Sangodoyin, 1993; Abegunrin, 2014).

As a result of the global crisis of potable water shortage, alternative water resources are sought and rainwater harvesting is a major method among several strategies for mitigating the growing water crisis (Ayoade et al., 1998; Cooker, 1999; Lucas et al., 2005; Hatibu et al., 2006; Hartung, 2007; Ghisi and Ferreira, 2007). Rainwater, according to Thomas (2000) is considered to be purer for potable or non-potable purposes than water from other sources. Although rainwater has been reported to be relatively acceptable quality for many purposes (Ariyabandu, 1999; Li et al., 2000; Andrew-Lo, 2003), however, one of the primary issues regarding the use of rainwater is quality (Despins et al., 2009).

Deteriorations during harvesting, catchment material, storage and household use have been reported (WHO, 2011). External pollution sources such as proximity to major roads or heavy industries, the presence of birds or rodents have the potential to affect rainwater quality (Simmons et al., 2001; Chang et al., 2004; Zhu et al., 2004; Sazakli et al., 2007; Abegunrin et al., 2014). According to Forter (1999) and Lee et al., (2010), heavy metals have been found in harvested rainwater while Ahmed et al., (2008) reported the presence of pathogenic bacteria. Cleanliness, age and type of catchment, atmospheric conditions and storage also contribute to the quality of harvested rainwater (Yaziz et al., 1989; Simmons et al., 2001; Chang et al., 2004; Zhu et al., 2004; WHO, 2011).

Storage may be a source of contamination to harvested rainwater over time. While storage in cisterns is somewhat considered to enhance the quality of rainwater, however there is concern over the potential for chemical (Despins et al., 2009). For instance,one study reported significant leaching of zinc from metallic storage tank. To the best of our knowledge, we are not aware of any reported work on the combine effects of storage duration and materials on the quality of harvested rainwater in Ogbomoso, southwestern Nigeria.

We hypothesized that materials and duration of storage have significant effects on the quality of harvested rainwater. This study therefore examined the combined effects of storage duration and materials on the physicochemical and microbiological qualities of harvested rainwater in Ogbomoso, Southwestern Nigeria.

\section{Materials and Methods}

\section{Description of the study area}

The study was carried out in Ogbomoso township $\left(8^{\mathrm{o}} 10^{\prime} \mathrm{N}, 4^{\mathrm{o}} 10^{`} \mathrm{E}\right)$ southwest Nigeria. Ogbomoso Township comprises of Ogbomoso South Local Government (OSLG) and Ogbomoso North Local Government (ONLG) (Figure 1). The mean annual rainfall is about $1200 \mathrm{~mm}$ and the mean maximum and minimum temperatures are 33 and $28^{\circ} \mathrm{C}$, respectively. The relative humidity of the area is relatively high (approximately 74\%) throughout the year except in January when the dry wind blows from the North (Olaniyi et al., 2010). Majority of the residents depend on groundwater (Adetunde et al., 2011) due to inadequate supply from the Ogbomoso zone of the Oyo State Water Corporation (Toyobo et al., 2011). Toyobo (2013) however reported that most households have no access to well and borehole water due to their poor income. This situation forced many residents to collection and storage of rainwater in 
different storage facilities available to meet their water demands for few days.

\section{Water sample collection}

A preliminary survey of the common storage materials in use was carried out and it was found that the major storage materials in use are metals (M), usually used oil drums, PVC tanks (P), mostly black colour and earthen pots (E). These common storage materials were used for this study. The three types of storage materials were purchased, thoroughly washed and kept under the same conditions. Rainwater was collected on a galvanized iron roofing sheet and same quantity of 100 litres was kept in each storage type. The roof was allowed to be cleaned by allowing rainwater to run over it for sometimes before the water for storage was collected as recommended by Yaziz et al., (1989).

A total of 162 samples were collected; 81 samples from each of OSLG and ONLG, respectively. In each of the local governments, 27 samples (in triplicates) were collected from each of the storage type. This translates to 9 samples from each storage duration (1, 5 and 10 days after storage, designated as D1, D5 and D10, respectively). The sample bottles used have been previously soaked in diluted $\mathrm{HNO}_{3}$ acid for 24 hours after which they were thoroughly washed with detergent and rinsed with distilled water. The water samples were collected in the treated samples bottles.

Samples for heavy metals were acidified with concentrated $\mathrm{HNO}_{3}$ to keep the metals in solution and to minimize their adsorption to the wall of the sample bottles. Samples for microbial analysis were kept in sterilized capped bottles to curb further growth of bacteria. All sample bottles were kept in icepack and transported to the laboratory immediately.

\section{Laboratory analysis}

The physico-chemical parameters tested include $\mathrm{pH}$, total hardness $(\mathrm{TH})$, turbidity, electrical conductivity (EC) temperature, total solids (TS), $\mathrm{Ca}^{2+}, \mathrm{Mg}^{2+}, \mathrm{Al}^{3+}, \mathrm{Pb}^{2+}, \mathrm{Cl}^{-}, \mathrm{NO}_{3}{ }^{2-}$, $\mathrm{NO}_{2}{ }^{2-}$. Microbial parameters analyzed were Total Bacterial Count (TBC)and Total Coliform Count (TC). Each water sample was analyzed based on the procedures described by APHA (1998).

\section{Statistical analysis}

Analysis of variance (ANOVA) was carried out on the water physical, chemical and microbiological characteristics and Fisher's LSD test was used to determine significant difference between individual means at 5\% level of probability. Statistical analyses were done using SPSS (version 20).

\section{Results and Discussion}

\section{Effect of storage materials on harvested rainwater quality}

The results of the effects of storage materials on the physico-chemical and microbiological properties of rainwater are presented in Figure 2. Values of $\mathrm{pH}$ of water from the different storage materials were recorded as 6.41, 6.39 and 8.06 for metal drum (M), plastic drum (P) and earthen pot $(\mathrm{E})$, respectively. The $\mathrm{pH}$ of water in metal and plastic storage materials were within the slightly acidic range while that of earthen pot was 8.06 and within the slightly alkaline range (Figure 2 a). The $\mathrm{pH}$ value of water in plastic material may be the actual $\mathrm{pH}$ value of the rainwater since $\mathrm{PVC}$ is inert. The $\mathrm{pH}$ value of water in storage earthen pot was significantly different from those in metal and plastic storage materials. The alkaline $\mathrm{pH}$ of water (>7.0) recorded in earthen pot may be due to the material from which the pot is made of. It is suspected that the material of the earthen pot contain some 
calcium salt that has been dissolved by the water stored in it. Water with $\mathrm{pH}>11$ has been reported to cause eye irritation and exacerbation of skin disorders while water with $\mathrm{pH}<4$ was found to cause redness and eye irritation, the severity of which can increase with decreasing $\mathrm{pH}$ (WHO, 1986). Furthermore, water with high $(>11)$ or low $(<6.5) \mathrm{pH}$ can lead to corroding of water supply pipes and fittings. Thus, the average $\mathrm{pH}$ values of the rainwater observed in our study indicate "safe" in terms of public health.

The average values of water temperature in metal drum, plastic drum and earthen pot were $23.92,24.17$ and $24.17^{\circ} \mathrm{C}$, respectively. These values showed no significant differences, in other words, the storage media did not significantly affect the temperature. The insignificant effect of material on water temperature is attributed to sampling done during summer time in which there is no much variation in ambient temperature.

The mean values for turbidity from the different storage media showed significant differences with highest value of 6.26 NTU obtained in water stored in metal drum and lowest for water stored in plastic drum (1.68 NTU) with earthen pot having a value of 1.95 NTU. Electrical conductivity values of water samples from the storage materials were $20.93,23.26$ and $180.29 \mu \mathrm{S} / \mathrm{cm}$ in metal drum, plastic drum and earthen pot, respectively (Figure 2 a). The value EC for water stored in the earthen pot was highest and significantly different from those in the metal and plastic drums. This may be due to the dissolution of particle of materials from the earthen pot into the water. The average values of TS of the rainwater sampled from the different storage materials were 86.10, 102.04 and.132.94 $\mathrm{mg} / \mathrm{L}$ for the metal drum, plastic drum and earthen pot, respectively. The mean value observed in earthen pot was significantly different from those in metal and plastic drums. This also may be due to the particles from the earthen pots that have dissolved in the water. From the observation in the different storage media, total hardness (TH) value of zero (0) was recorded for metal and plastic storage materials while $59.06 \mathrm{mg} / \mathrm{L}$ was observed in earthen pot (Figure 2 a). This may also be attributed to the release of the component materials of the earthen pot.

The average values of $\mathrm{Cl}$ obtained for water stored in metal drum, plastic drum and earthen pot were 5.45, 5.33 and $6.59 \mathrm{mg} / \mathrm{L}$, respectively, with no significant difference (p $<0.05)$ in $\mathrm{Cl}$ concentration of water from all the three storage media (Figure $2 \mathrm{~b}$ ). Nitrate $\left(\mathrm{NO}_{3}\right)$ values in the different storage materials also showed significant differences with values $0.02,0.12$ and $0.36 \mathrm{mg} / \mathrm{L}$ recorded respectively for metal drum, plastic drum and earthen pot. The average concentration of $\mathrm{NO}_{2}$ from metallic drum, plastic drum and earthen pot was 1.23, 0.01 and $0.20 \mathrm{mg} / \mathrm{L}$, respectively, without significant differences among the storage materials.

$\mathrm{Ca}$ and $\mathrm{Mg}$ were not recorded in metal and plastic storage drums while $6.36 \mathrm{mg} / \mathrm{L} \mathrm{Ca}$ and $1.45 \mathrm{mg} / \mathrm{L} \mathrm{Mg}$ were recorded in earthen pot (Figure $2 \mathrm{c}$ ). The values recorded in the earthen pot may be due to the material from which the pot is made of. It is suspected that the material of the earthen pot contain some calcium and magnesium salts that have been dissolved. Trace metals $\mathrm{Pb}$ and $\mathrm{Al}$ were not detected in the water samples for the different storage materials (Figure $2 \mathrm{c}$ ). The absence of these toxic metals is desirable because of the danger they pose to human health.

The total bacterial count (TBC) was significantly different in the storage media with average values highest in plastic drum (362.00 MPN/100ml) and lowest in earthen pot (105.11 MPN/100ml) (Figure 2 d). The 
lowest value in the earthen pot could be as a result of $\mathrm{pH}$ value of the rainwater as water sampled from earthen pot had the highest value of $\mathrm{pH}$. Studies have found some correlations between $\mathrm{pH}$ and growth of coliforms in rainwater tanks (Zhu et al., 2004). In agreement with our findings, Achadu et al., (2013) also reported highest values of TBC in plastic storage medium. Total coliform (TC) was 10.56, 9.11 and $33.89 \mathrm{CFU} / 100 \mathrm{ml}$ in storage materials made of metal, plastic and earthen pot, respectively (Figure $2 \mathrm{~d}$ ), and these values differed significantly. This difference could be as a result of variations in water handling in the different storage types.

\section{Effect of storage duration on rainwater quality}

The results of the effects of storage duration on the physico-chemical and microbiological properties of harvested rainwater are presented in Figure 3. The average $\mathrm{pH}$ values of the harvested rainwater stored for one day $\left(D_{1}\right)$, five days $\left(D_{5}\right)$ and ten days $\left(\mathrm{D}_{10}\right)$ were $6.79,7.04$ and 7.02 , respectively (Figure 3 a). These values were within the acceptable range of6.5 - 8.5 for drinking water standards (WHO, 2011; NSDWQ, 2007), and complied with the previous findings of other studies (Olaoye and Olaniyan, 2013; Abegunrin et al., 2014). In our study, there was no significant difference $(\mathrm{p}<0.05)$ in the average $\mathrm{pH}$ values from the different storage periods.

Significant difference $(\mathrm{p}<0.05)$ was observed in the temperature of the water for the different storage duration. The mean temperatures were $26.97,17.77$ and $27.52^{\circ} \mathrm{C}$ for storage durations one, five and ten days, respectively. The difference in temperature may be attributed to ambient conditions which vary with time. The turbidity was least (3.05 NTU) for one day and highest (3.65 NTU) after five days of storage. Although the values of turbidity in the water stored for different duration were not the same, the differences were not statistically difference. Nevertheless, the variation in the values of turbidity may be due to the presence of settle able particles in water as well as the effect of environmental conditions. After the first day of storage $\left(\mathrm{D}_{1}\right)$, some settleable particles may have settled and thus reduced the turbidity. However, higher value after five days of storage $\left(D_{5}\right)$ may be due to "disturbance" of the stored water causing the settled particles to mix with the water and raise the turbidity level once again. The lower value of 3.20 NTU after ten days of storage $\left(\mathrm{D}_{10}\right)$ could be due to resettlement of the settleable particles when the stored water is in quiescent condition. The average values of electrical conductivity (EC) were 53.43, 72.33 and $98.72 \mu \mathrm{S} / \mathrm{cm}$ for one, five and ten days of storage respectively. The EC values of the stored water for the three storage durations showed an increasing trend from one day to ten days though the values are not statistically different $(p<0.05)$.

The increased trend indicated that more particles were dissolved in the stored water as storage duration is increasing. The total solid (TS) increased with storage duration (91.01, 98.67 and $131.40 \mathrm{mg} / \mathrm{L}$ for one, five and ten days, respectively) with significant differences $(\mathrm{p}<0.05)$ observed among the different storage durations. This increase in TS may be due to the dissolution of more particles in the stored water as storage duration increases.

In deviation to the trend observed in EC and TS, the values for total hardness fluctuated for storage duration. The $\mathrm{TH}$ values for one, five and ten days of storage were 26.44, 6.50 and $26.11 \mathrm{mg} / \mathrm{L}$, respectively (Figure $3 \mathrm{a}$ ). The values for one and ten days of storage did not differ significantly $(\mathrm{p}<0.05)$ however they differed significantly from that of five days of storage. 
Table.1 Interactive effect of storage duration and type of storage material on the physical properties of the harvested rainwater

\begin{tabular}{|c|c|c|c|c|c|c|c|}
\hline Duration & Material & $\begin{array}{c}\mathrm{pH} \\
-\end{array}$ & $\begin{array}{c}\text { Temp. } \\
\left({ }^{\circ} \mathrm{C}\right)\end{array}$ & $\begin{array}{l}\text { Turb. } \\
\text { (NTU) }\end{array}$ & $\begin{array}{c}\mathrm{EC} \\
(\mu \mathrm{S} / \mathrm{cm})\end{array}$ & TS & TH \\
\hline \multirow{3}{*}{ D1 } & M & 6.33 & 26.9 & 5.33 & 21.0 & 56.1 & $6.00 \mathrm{E}-15$ \\
\hline & $\mathrm{P}$ & 6.40 & 26.9 & 1.69 & 21.4 & 92.3 & 7.77E-16 \\
\hline & $\mathrm{E}$ & 7.63 & 27.1 & 2.12 & 117.8 & 124.6 & 7.93E+01 \\
\hline \multirow{3}{*}{ D5 } & M & 6.47 & 17.8 & 6.51 & 20.5 & 74.0 & $0.00 \mathrm{E}+00$ \\
\hline & $\mathrm{P}$ & 6.37 & 18.0 & 1.92 & 17.9 & 90.8 & $0.00 \mathrm{E}+00$ \\
\hline & $\mathrm{E}$ & 8.30 & 17.5 & 2.51 & 178.7 & 131.3 & $1.95 \mathrm{E}+01$ \\
\hline \multirow{3}{*}{ D10 } & M & 6.43 & 27.0 & 6.95 & 21.3 & 128.2 & $0.00 \mathrm{E}+00$ \\
\hline & $\mathrm{P}$ & 6.40 & 27.6 & 1.43 & 30.5 & 123.0 & $1.42 \mathrm{E}-14$ \\
\hline & $\mathrm{E}$ & 8.23 & 28.0 & 1.22 & 244.4 & 142.9 & 7.83E+01 \\
\hline D x Mat. & & $\mathrm{s}$ & $\mathrm{s}$ & $\mathrm{s}$ & $\mathrm{s}$ & $\mathrm{s}$ & $\mathrm{s}$ \\
\hline
\end{tabular}

Temp = Temperature; Turb = Turbidity; EC = Electrical Conductivity; TS $=$ Total Solid;TH $=$ Total Hardness D1: storage for 1 day; D5: storage for 5 days; D10: storage for 10 days; M: metal storage structure; P: Plastic storage structure and E: earthen pot.

D x Mat: interaction between storage duration and material; s: significant difference at $5 \%$ level of probability by LSD test.

Table.2 Interactive effect of storage duration and type of storage material on chemical properties of the harvested rainwater

\begin{tabular}{|c|c|c|c|c|c|c|c|c|}
\hline Duration & Material & $\mathrm{Ca}$ & $\mathrm{Mg}$ & $\mathrm{Al}$ & $\mathrm{Pb}$ & $\mathrm{Cl}^{-}$ & $\mathrm{NO}_{2}$ & $\mathrm{NO}_{3}$ \\
\hline \multirow{4}{*}{ D1 } & $\mathrm{M}$ & 0.00 & 0.00 & nd & nd & 4.02 & 0.03 & 3.67 \\
\hline & $\mathrm{P}$ & 0.00 & 0.00 & nd & nd & 4.48 & 0.04 & 0.02 \\
\hline & $\mathrm{E}$ & 9.20 & 1.45 & nd & nd & 5.40 & 0.85 & 0.42 \\
\hline & $\mathrm{M}$ & 0.00 & 0.00 & nd & nd & 5.32 & 0.00 & 0.01 \\
\hline \multirow[t]{2}{*}{ D5 } & $\mathrm{P}$ & 0.00 & 0.00 & nd & nd & 4.45 & 0.03 & 0.01 \\
\hline & $\mathrm{E}$ & 6.47 & 1.10 & nd & nd & 5.44 & 0.03 & 0.02 \\
\hline \multirow{3}{*}{ D10 } & M & 0.00 & 0.00 & nd & nd & 7.00 & 0.01 & 0.00 \\
\hline & $\mathrm{P}$ & 0.00 & 0.00 & nd & nd & 7.05 & 0.31 & 0.01 \\
\hline & $\mathrm{E}$ & 3.41 & 1.80 & nd & nd & 8.92 & 0.22 & 0.15 \\
\hline D x Mat. & & $\mathrm{s}$ & $\mathrm{S}$ & - & - & $\mathrm{s}$ & $\mathrm{s}$ & $\mathrm{s}$ \\
\hline
\end{tabular}

Ca: calcium; $\mathrm{Mg}$ : magnesium; $\mathrm{Pb}$ : lead; $\mathrm{Al}$ : aluminum; $\mathrm{Cl}$ : chloride; $\mathrm{NO}_{3}$ : nitrate; $\mathrm{NO}_{2}$ : nitrite

D1: storage for 1 day; D5: storage for 5 days; D10: storage for 10 days; M: metal storage structure; P: Plastic storage structure and E: earthen pot.

D x Mat: interaction between storage duration and material; s: significant difference at $5 \%$ level of probability by LSD test; nd: not detected 
Table.3 Parameters A, B and C of the regression equations and coefficient of determination (R2) for the quality indicators of harvested rainwater

\begin{tabular}{lcccc}
\hline & \multicolumn{3}{c}{ Fitting parameters } & \\
\cline { 2 - 4 } Property & $\mathrm{A}$ & $\mathrm{B}$ & $\mathrm{C}$ & $\mathrm{R}^{2}$ \\
\hline $\mathrm{pH}$ & 0.0076 & 0.109 & 6.687 & 0.0209 \\
Temp. & 0.4723 & -5.134 & 31.628 & 0.9966 \\
Turb. & -0.0267 & 0.309 & 2.767 & 0.0138 \\
$\mathrm{EC}$ & 0.0614 & 4.356 & 49.016 & 0.0534 \\
$\mathrm{TS}$ & 0.5147 & -1.175 & 91.672 & 0.3912 \\
$\mathrm{TH}$ & 0.9898 & -10.925 & 36.38 & 0.0839 \\
$\mathrm{Ca}$ & 0.0027 & -0.244 & 3.308 & 0.0573 \\
$\mathrm{Mg}$ & 0.0084 & -0.079 & 0.556 & 0.0181 \\
$\mathrm{Cl}$ & 0.0454 & -0.164 & 4.753 & 0.8016 \\
$\mathrm{NO}_{3}$ & 0.0115 & -0.141 & 0.436 & 0.2049 \\
$\mathrm{NO}_{2}$ & 0.0386 & -0.571 & 1.904 & 0.3089 \\
\hline
\end{tabular}

Temp. $=$ Temperature; Turb $=$ Turbidity; EC $=$ Electrical Conductivity; TS $=$ Total Solid;TH = Total Hardness; Ca: calcium; Mg: magnesium; $\mathrm{Pb}$ : lead; $\mathrm{Al}$ : aluminum; Cl: chloride; $\mathrm{NO}_{3}$ : nitrate; $\mathrm{NO}_{2}$ : nitrite $\mathrm{R}^{2}$ : Coefficient of determination

Table.4 Pearson correlation among the evaluated quality indicators of the harvested rainwater

\begin{tabular}{|c|c|c|c|c|c|c|c|c|c|c|c|}
\hline Par. & $\mathrm{pH}$ & Temp. & Turb. & $\mathrm{EC}$ & $\mathrm{TS}$ & $\mathrm{TH}$ & $\mathrm{Ca}$ & $\mathrm{Mg}$ & $\mathrm{Cl}$ & $\mathrm{N}-\mathrm{NO}_{3}$ & $\mathrm{~N}-\mathrm{NO}_{2}$ \\
\hline $\mathrm{pH}$ & 1 & & & & & & & & & & \\
\hline Temp & -0.065 & 1 & & & & & & & & & \\
\hline Turb & $-0.413^{*}$ & -0.145 & 1 & & & & & & & & \\
\hline $\mathrm{EC}$ & $0.959^{* *}$ & 0.052 & $-0.458^{*}$ & 1 & & & & & & & \\
\hline TS & $0.621^{* * *}$ & 0.222 & -0.377 & $0.615^{* *}$ & 1 & & & & & & \\
\hline $\mathrm{TH}$ & $0.769^{* * *}$ & 0.316 & $-0.433^{*}$ & $0.802^{* *}$ & $0.522^{* *}$ & 1 & & & & & \\
\hline $\mathrm{Ca}$ & $0.797^{* *}$ & -0.016 & -0.357 & $0.687^{* *}$ & $0.480^{*}$ & $0.783^{* *}$ & 1 & & & & \\
\hline $\mathrm{Mg}$ & $0.937^{* *}$ & 0.141 & $-0.459^{*}$ & $0.942^{* *}$ & $0.594^{* *}$ & $0.938^{* *}$ & $0.826^{* *}$ & 1 & & & \\
\hline $\mathrm{Cl}$ & $0.442^{*}$ & $0.391^{*}$ & -0.167 & $0.577^{* *}$ & $0.697^{* *}$ & $0.478^{*}$ & 0.107 & $0.495^{* *}$ & 1 & & \\
\hline $\mathrm{N}-\mathrm{NO}_{3}$ & 0.348 & $0.410^{*}$ & $-0.403^{*}$ & 0.301 & 0.354 & $0.729^{* *}$ & $0.709^{* *}$ & $0.556^{* *}$ & 0.168 & 1 & \\
\hline $\mathrm{N}-\mathrm{NO}_{2}$ & -0.079 & 0.157 & 0.180 & -0.102 & -0.099 & -0.066 & -0.075 & -0.090 & -0.226 & -0.037 & 1 \\
\hline
\end{tabular}

*Correlation is significant at the 0.05 level (2-tailed).

$* *$ Correlation is significant at the 0.01 level (2-tailed).

Temp $=$ Temperature Turb $=$ Turbidity $; \mathrm{EC}=$ Electrical Conductivity $; \mathrm{TS}=$ Total Solid $; \mathrm{TH}=$ Total Hardness 
Fig.1 Map of Ogbomoso Township, southwest Nigeria

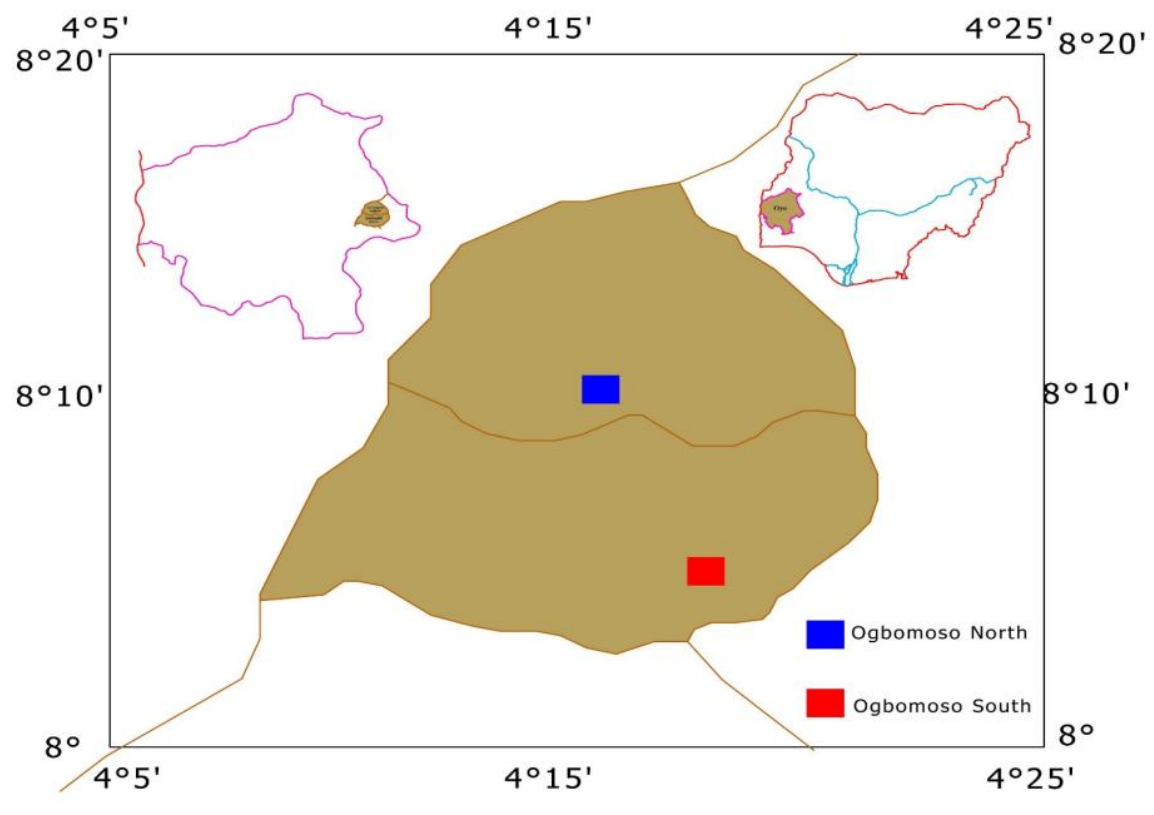

Fig.2 Effects of storage materials on a) physical properties, b) nitrates and chloride, c) cations and d) microbiological properties of harvestedrainwater
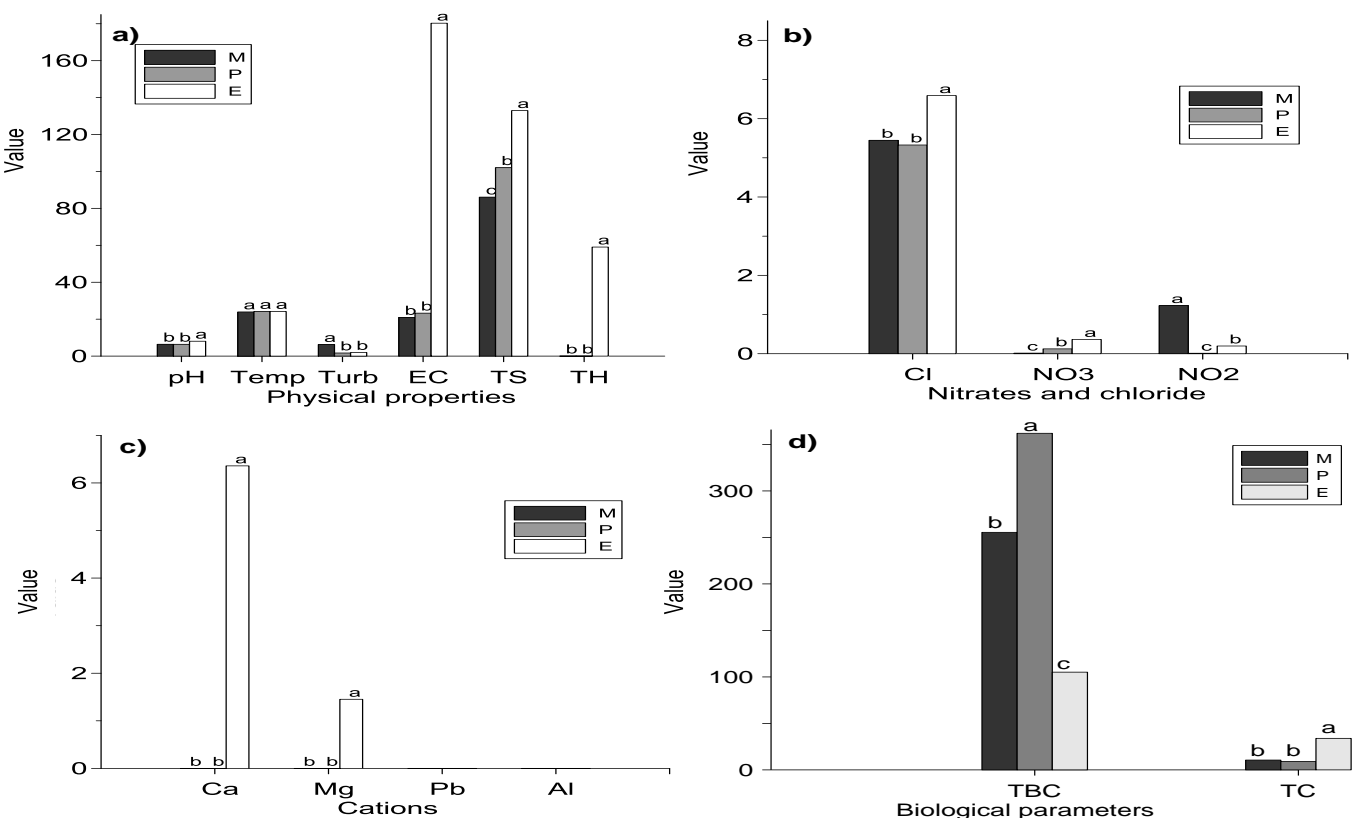

Temp $=$ Temperature $\left({ }^{\circ} \mathrm{C}\right) ;$ Turb $=$ Turbidity $(\mathrm{NTU}) ; \mathrm{EC}=$ Electrical Conductivity $(\mu \mathrm{S} / \mathrm{cm}) ; \mathrm{TS}=$ Total Solid $(\mathrm{mg} / \mathrm{L}) ; \mathrm{TH}=$ Total Hardness $(\mathrm{mg} / \mathrm{L}) ; \mathrm{Cl}$ : chloride, $\mathrm{mg} / \mathrm{L} ; \mathrm{NO}_{3}$ : nitrate, $\mathrm{mg} / \mathrm{L} ; \mathrm{NO}_{2}$ : nitrite, $\mathrm{mg} / \mathrm{L} ;$ Ca: calcium, mg/L; Mg: magnesium, mg/L; Pb: lead, mg/L; Al: aluminum, mg/L; TBC: total bacterial count, MPN/100ml; TC: total coliform, $\mathrm{CFU} / 100 \mathrm{ml}$.

M: metal storage structure; P: Plastic storage structure and E: earthen pot.

Bars with different letters differed significantly at 5\% level of probability by Fisher's LSD test. 
Fig.3 Effects of storage duration on a) physical properties, b) nitrates and chloride, c) cations and d) microbiological properties of harvested rainwater
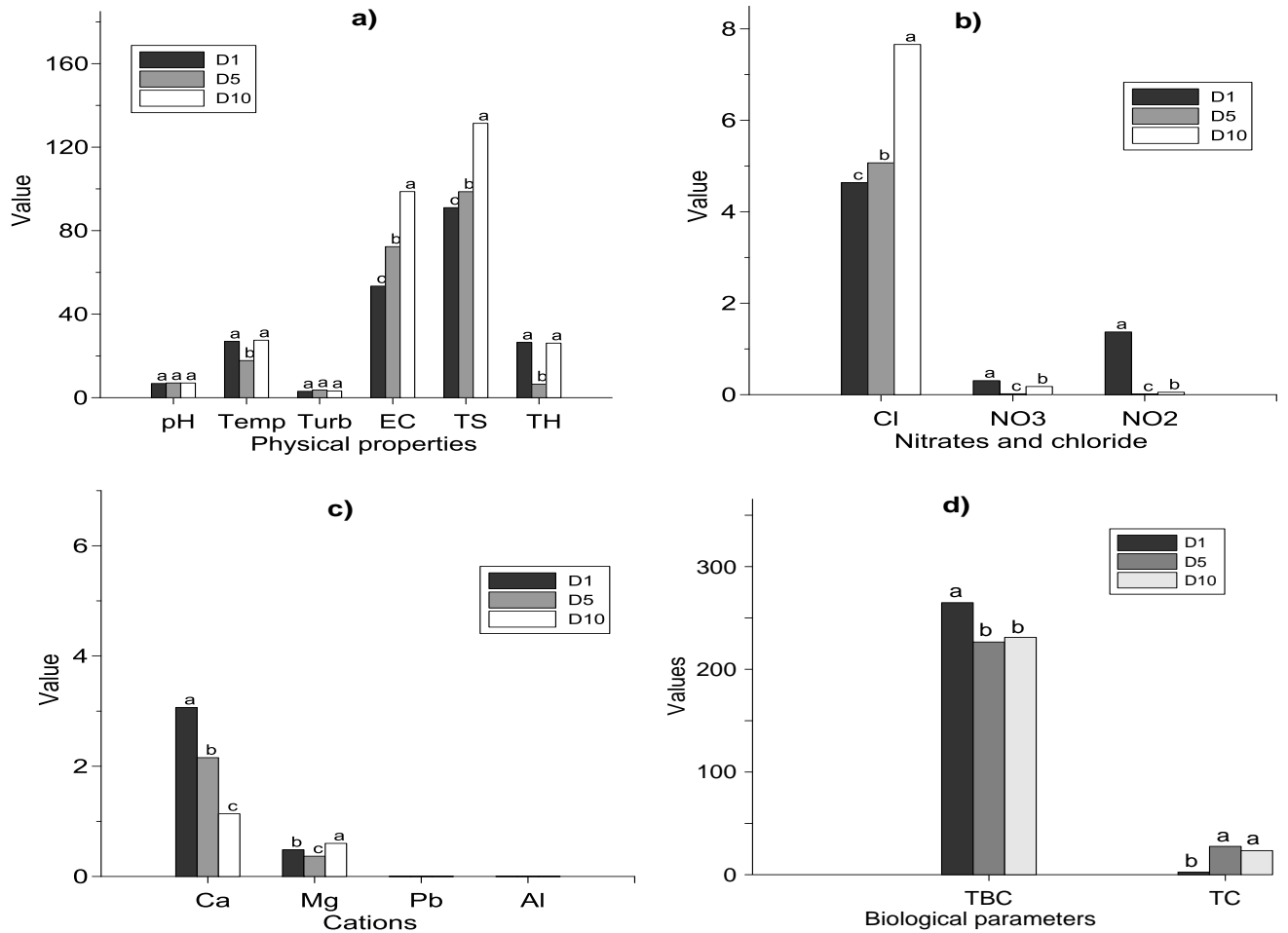

Temp $=$ Temperature $\left({ }^{\circ} \mathrm{C}\right) ;$ Turb $=$ Turbidity $(\mathrm{NTU}) ; \mathrm{EC}=$ Electrical Conductivity $(\mu \mathrm{S} / \mathrm{cm}) ; \mathrm{TS}=$ Total Solid $(\mathrm{mg} / \mathrm{L}) ; \mathrm{TH}=$ Total Hardness $(\mathrm{mg} / \mathrm{L}) ; \mathrm{Cl}$ : chloride, $\mathrm{mg} / \mathrm{L} ; \mathrm{NO}_{3}$ : nitrate, $\mathrm{mg} / \mathrm{L} ; \mathrm{NO}_{2}$ : nitrite, $\mathrm{mg} / \mathrm{L} ; \mathrm{Ca}$ : calcium, $\mathrm{mg} / \mathrm{L} ; \mathrm{Mg}$ : magnesium, mg/L; $\mathrm{Pb}$ : lead, mg/L; Al: aluminum, mg/L; TBC: total bacterial count, MPN/100ml; TC: total coliform, CFU/100ml.

D1: storage for 1 day; D5: storage for 5 days; D10: storage for 10 days

Bars with different letters differed significantly at $5 \%$ level of probability by Fisher's LSD test.

There were differences in the values 4.63, 5.07 and $7.66 \mathrm{mg} / \mathrm{L}$ of $\mathrm{Cl}$ observed for storage durations of one, five and ten days, respectively (Figure $3 b$ ). These differences are however not significant $(\mathrm{p}<0.05)$. The average values of nitrate $\left(\mathrm{NO}_{3}\right)$ were significantly different for the storage duration, with values $0.31,0.02$ and $0.18 \mathrm{mg} / \mathrm{L}$ recorded for $D_{1}, D_{5}$ and $D_{10}$, respectively. The average concentration of $\mathrm{NO}_{2}$ for one, five and ten days of storage was $1.37,0.01$ and 0.05 , respectively. These values were not significantly different. The average values of $\mathrm{Ca}$ and $\mathrm{Mg}$ for one, five and ten days of storage, respectively were $3.07,2.16$ and 1.14 $\mathrm{mg} / \mathrm{L}$ and $0.48,0.37$ and $0.60 \mathrm{mg} / \mathrm{L}$. There was no significant difference in both the $\mathrm{Ca}$ and $\mathrm{Mg}$ levels for the three storage durations
(Figure 3c). The decreasing values in Ca level may be attributed to the settlement of particles in the water as the storage duration increases. Trace metals $\mathrm{Pb}$ and $\mathrm{Al}$ were not detected in the water samples for the different storage durations.

Rainwater stored for one day $\left(\mathrm{D}_{1}\right)$ had the highest total bacterial count (TBC) value of 264.89 MPN/100ml while five days $\left(D_{5}\right)$ of storage had the least value of 226.56 MPN/100ml (Figure 3d). The decrease in the TBC may be attributed to the condition of storage such as presence of light or otherwise. The difference in the TBC of the stored rainwater was however not significant. The total coliform (TC) for one, five and ten days of storage were 2.56, 27.56 and 23.44 
CFU/100ml, respectively. The TC of water sample after one day of storage differed significantly $(p<0.05)$ from those stored for five and ten days, but the TC of water stored for five days did not differ from that stored for ten days. This significant higher TC after five and ten days compared to just a day could be as a result of exposure to contamination by birds and rodents as well as unhygienic water handling practices which involves unsanitary use of utensils and hands touching the water. This result agrees with studies carried out by Pinfold (1990) who found that the most common route of contamination of stored water or the presence of coliform bacteria in stored water is through water handling such as dipping.

\section{Interactive effect of storage duration and material on rainwater quality}

The interactive effect of both storage duration and storage materials on the physical and chemical quality indicators of harvested rainwater is presented in Tables 1 and 2. The interactive effect of both storage duration and storage materials was significant $(\mathrm{p}<0.0)$ for all the physical parameters evaluated (Table 1). Similarly, the interactive effect of both storage duration and storage materials was significant $(\mathrm{p}<0.0)$ for all chemical characteristics except $\mathrm{Al}$ and $\mathrm{Pb}$ that were not detected (Table 2). The significant interaction observed on rainwater quality indicators indicates that both storage duration and materials could co-limit these indicators.

Irrespective of storage material, the regression analysis carried out on the rainwater quality indicators with storage time showed that changes in rainwater quality indicators over time can be best predicted using polynomial fitting of the second degree as:

$Q I=A t^{2}+B t+C \ldots \ldots \ldots \ldots \ldots \ldots \ldots . .1$

where $Q I$ is a quality indicator; $t$ is storage time, days; $A_{y} B_{s} C$ fitting parameters.
The parameters (A, B and C) of the regression equations as well as the coefficient of determination $\left(\mathrm{R}^{2}\right)$ for the quality indicators of harvested rainwater are presented in Table 3. Even with the polynomial fitting, only changes rainwater quality indicators of water temperature and chloride can be effectively predicted over time. Amin et al., (2013) found exponential fitting for predicting changes in microbial water quality of harvested rainwater over time.

\section{Correlation between properties}

The results of the pearson correlation analysis of the quality indicators of the rainwater are presented in Table 4. Except for water temperature and $\mathrm{N}-\mathrm{NO}_{2}$, there was significant correlation between the quality indicators. For example, the $\mathrm{pH}$ showed significant $(\mathrm{p}<0.05)$ positive correlation with $\mathrm{EC}, \mathrm{TS}, \mathrm{TH}, \mathrm{Ca}, \mathrm{Mg}$ and $\mathrm{Cl}$, the highest with EC while the correlation was negative and significant for temperature and turbidity. The turbidity correlated significantly with $\mathrm{EC}, \mathrm{TH}, \mathrm{Mg}$ and $\mathrm{N}-\mathrm{NO}_{3}$, however the correlation was negative. The EC had significant and positive correlation with TS, TH, Ca, Mg and $\mathrm{Cl}$. Both TS and TH correlate significantly with $\mathrm{Ca}, \mathrm{Mg}$ and $\mathrm{Cl}$.

It can be concluded that the study assessed the impacts of short term storage duration and material on the quality of harvested rainwater. Storage type had significant differences on the quality indicators except for temperature, $\mathrm{Cl}$ and $\mathrm{NO}_{2}$ whereas storage duration did not significantly affect the quality indicators except for temperature, $\mathrm{TS}, \mathrm{NO}_{3}$ and $\mathrm{TC}$.

Earthen pot most significantly influenced the quality of the water due to the high tendency of its constituent component to get dissolved in the water. As the storage duration increases, there is a great likelihood of the introduction of contamination particles as evidenced with the increasing trend of EC, TS and TC. There was significant correlation between the rainwater quality indicators and of all the quality indicators, only changes in water temperature 
and chloride can be best predicted over time.

This study shows that harvested rainwater for potable purposes should not be stored more than five days without adequate treatment and the use of plastic drum is recommended for storing rainwater. Nevertheless, care must be taken when storing rainwater from the introduction of foreign contaminants while proper handling must be ensured.

\section{References}

Abegunrin, T. P. 2014. Development and evaluation of rainwater harvesting model for domestic supply in southwestern Nigeria. An Unpublished $\mathrm{PhD}$ Thesis submitted to the Postgraduate School, University of Ibadan, Ibadan, Nigeria.

Abegunrin, T. P., A. Y.Sangodoyin, J. Odeniyi, and Onofua, O. E. 2014.Roof age effect on the quality of harvested rainwater and its health implication in a selected location, Southwest Nigeria. International Journal of Water Resources and Environmental Engineering. 6(10), 261266.

Adetunde, L.A., R.L.K. Glover, and Oguntola, G.O. 2011. Assessment of the ground water quality in Ogbomoso township of Oyo State of Nigeria. IJRRAS. 8(1), 115122.

Amin, M.T., T. Kim, M. N. Amin, and Han, M. Y. 2013. Effects of catchment, first-flush, storage conditions and time on microbial quality in rainwater harvesting systems. Water Environ. Res. 85, 2317-2329.

Andrew-Lo, K. F. 2003. Rainwater harvesting and utilization. Proceedings of International Training Course on Rainwater Harvesting and Utilization.138-149.

Ahmed, W., F.Huygens, A. Goonetilleke, and Gardner, T. 2008.Real-time PCR detection of pathogenic micro-organisms in roof-harvested rainwater in South-East Queensland, Australia.Applied and Environmental Microbiology. 74(17),5490-5496

Ayoade, J. O., A. Iwayemi, and Akintola, F. O. 1998.Urban water supply and demand in
Nigeria in an era of economic liberalization. Agroclimatology, Ibadan. Vantage Publisher.1-4.

Chang, M., M. W. Mcbroom, and Scott Beasley, R. 2004.Roofing as a source of non-point water pollution.J. Environ Manag. 73:307-15

Coker, A. 1999.Potentials of rainwater in a Southwestern Nigerian community. In: Hans Hartung (ed.). The Rainwater Harvesting $C D$ (2000).Margrof Publishers, Weikersheim, Germany.

Despins, C., K. Farahbakhsh, and Leidi, C. 2009.Assessment of rainwater quality from rainwater harvesting systems in Ontario, Canada.Journal of Water Supply, Research and Technology58(2), 117-134. Doi: 10.2166/aqua.2009.013.

Forter, J. 1999.Variability of roof runoff quality.Water Science and Technology. 39(5), 137-144

Ghisi, E., and Ferreira, D.F. 2007.Potential for potable water savings by using rainwater and greywater in multi-storey residential building in Southern Brazil.Build Environ. 42, 2512-2522.

Hartung, H. 2007. Rainwater utilization in Africa: Some experiences. Proceedings of the $1^{\text {st }}$ International Water Association Rainwater Harvesting and Management Specialist Group (IWA WHM SG), Seoul National University Brain Korea21 Sustainable Infrastructure Research Group (SNU BK21 SIR Group), United Nation Environmental Programme (UNEP), Seoul, Korea.

Hatibu, N., Mutabazi, K., Senkondo, E.M. and Msangi, A.S.K. (2006).Economics of rainwater harvesting for crop enterprises in semi-arid areas in East Africa.Agric. Water Manag.80:74-86.

IPCC 1990. Climate change: The Intergovernmental Panel on Climate Change Scientific Assessment. Report Prepares by working Group II, Canberra, Australian: Australian Government Publishing Service. Tegart W. J., Sheldon G.W., Griffiths D.C. (eds).

Kaldellis, J.K., and Kondili, E.M. 2007. The water shortage problem in the Aegean Archipelago Islands: Cost-effective 
Desalinization Prospects. Desalination 216, 123-38.

Lee, J.Y., J. S.Yang, M. Han, and Choi, J. 2010.Comparison of the microbiological and chemical characterization of harvested rainwater and reservoir water as alternative water resources.Science of the Total Environment. 408(4), 896-905.

Lucas, E.B., K. Ogedengbe, and Abegunrin, T.P. 2005.Guttering system design for rainwater harvesting applicable for Ibadan Metropolis, Nigeria.LAUTECH Journal of Engineering and Technology 3(2), 9398.

Matondo, J.I., G. Peter, AndMsibi, K.M. 2005.Managing water under climate change for peace and prosperity in Swaziland.Phys. Chem. Earth. 30, 943949.

Miller, B.A. 1989.Global Climate ChangeImplications of large water resource systems. Proceedings of the 1989 National Conference on Hydraulic Engineering, New Orleans, Louisiana.

Olaniyi, J.O., W.B.Akanbi, T. A.Adejumo, and Akande, O.G. 2010.Growth, fruit yield and nutritional quality of tomato varieties. African. J. Food Sci.4(6), 398-402.

Pinfold, J. V., J. N.Horan, W. Wirojanagud, and Mark, D. 1993. The bacteriological quality of rain jar water in rural northwest Thailand. Wat. Res. 27(2), 297-302.

Sangodoyin, A. Y. 1993. Considerations on contamination of groundwater by waste disposal systems in Nigeria. Environmental Technology. 14, 957-964.

Sazakli, E., A. Alexopoulous, and Leotsilidis, M. 2007. Rainwater harvesting: Quality assessment and utilization in Kefalonia Island, Greece. Water Res. 41(9), 2039-47

Simmons, G., V.Hope, G.Lewis, J. Whitmore, and Gao, W. 2001. Contamination of potable roof-collected rainwater in Auckland, New Zealand.Water Res. 35(6), 1518-24.

Thomas, T. 2000. Where is rainwater harvesting going? Waterlines. 18(3), 7-10

Toyobo, A.E. 2013. Residential access to borehole water supply in Ogbomosho North Local Government Area, Oyo State, Nigeria.Journal of Resources Development and Management. 1. 30-35.

Toyobo, A.E., A.B. Muili, and Ige, J. O. 2011.Correlates of socio-economic characteristics of housing in Ogbomosotownship, Oyo State, Nigeria. Global Journal of Human Social Science11(7),

World Health Organization(WHO) Working Group 1986. Health impact of acidic deposition.Sci. Total Environ. 52(3), 157187.

World Health Organization(WHO) 2011.Guidelines for drinking-water quality.World Health Organization, $4^{\text {th ed }}$. Geneva.

Yaziz, M.I., H. Gunting, L. Sapari, and Ghazali, A. W. 1989.Variations in rainwater quality from roof catchments. Water Res. 23(6), 761-5

Zhu, K., L.Zhang, W.Hart, M. Liu, and Chen, H. 2004. Quality issues in harvested rainwater in arid and semi-arid loss plateau of northern China. J. Arid Environ.57, 487-505.

\section{How to cite this article:}

Abegunrin, T.P., G.O. Awe, A.Y. Sangodoyin, O.E. Onofua and Oguntoye, O.M. 2017. Impacts of Storage Duration and Materials on the Quality of Rainwater in Ogbomoso, Southwest Nigeria. Int.J.Curr.Microbiol.App.Sci. 6(7): 4489-4500.

doi: https://doi.org/10.20546/ijcmas.2017.607.468 